\title{
SILĪCIJA PLŪSMU ILGTERMIṆA MAINĪBA LATVIJAS UPĒS
}

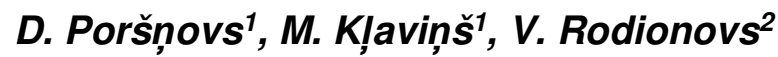 \\ ${ }^{1}$ LU G̣ZZF Vides zinātnes nodaḷa \\ ${ }^{2}$ LU Bioloǵijas institūts
}

\begin{abstract}
Anotācija. Virszemes ūdeṇu sastāva pētījumi ir ḷoti nozīmīgi, lai izprastu antropogēno faktoru, kā arī globālo Zemes sistēmu pārmaiņu ietekmi uz vidi. Izšḳīdušais silīcijs virszemes ūdeṇos ir atzīstams par nozīmīgu barības vielu, kas nepieciešama fitoplanktonam, diatomejām, kā arī ūdens augiem. Šī pētījuma mērḳis ir novērtēt silīcija koncentrāciju ilgtermiṇa mainību Latvijas iekšzemes ūdeṇos. Ir konstatētas būtiskas silīcija koncentrācijas pārmaiņas, kas norāda uz pārmaiṇām Latvijas upju sateces baseinos.

Atslēgas vārdi: silīcijs, augu barības vielas, Latvija, upju baseini.
\end{abstract}

\section{Ievads}

Virszemes ūdeņu sastāva pētījumi ir l,oti nozīmīgi, lai izprastu antropogēno faktoru, kā arī globālo Zemes sistēmu pārmaiņu ietekmi uz vidi. N̦emot vērā plaši izplatīto iekšzemes un piekrastes ūdeņu eitrofikāciju, īpaši aktuāli ir augu barības vielu (slāpekḷa, fosfora un silīcija) koncentrācijas un slodžu pētījumi. Ūdens kvalitātes rādītāju tendences var kalpot kā indikators nacionālās un starptautiskās vides politikas efektivitātes novērtēšanai (Brunet, Astin 1999; Donohue et al. 2001). N̦emot vērā temata aktualitāti, ir atrodams daudz pētījumu par augu barības vielu koncentrāciju un slodžu mainību (Zhang, Zhang 1995; Brakke et al. 1988; Ferrier et al. 2001; Interlandi and Crockett 2003). Nepieciešamība novērtēt sarežǵītus, vielu mobilitāti ietekmējošus procesus ūdenstilpēs un to sateces baseinos, ievērojami paaugstina ilgtermiņa pētījumu vērtību šajā jomā (Godwin et al. 2003). Augu barības vielu slodzes un to koncentrācijas pārmaiṇu tendences ir plaši pētītas Baltijas jūras reǵionā, šajos pētījumos visbiežāk ir izmantotas visai īsas (5-10 gadu) datu rindas (Löfgren et al. 1999; Klavins et al. 1999a; Stålnacke et al. 2003). Tomēr ir nepieciešams ņemt vērā, ka izšḳīdušo vielu slodze ir atkarīga no upju noteces, savukārt notece var būtiski main̄̄ties ne tikai sezonālu, bet arī daudzgadīgu svārstību ietekmē. Izškīidušais silīcijs virszemes, kā arī jūras ūdeņos ir atzīstams par nozīmīgu barības vielu, kas nepieciešama fitoplanktonam, diatomejām, un makrofìtiem (Raguenau et al. 2009) un ir viena no primārās produkcijas daudzumu regulējošām vielām. Galvenais silīcija avots ir silīcija savienojumus saturošo iežu dēdēšana, zināma loma piemīt arī biogēnu silīcijorganisku savienojumu sadalīšanās procesiem (Conley 2002). Reǵionālā mērogā silīcija noteci ietekmē arī tādi faktori sateces baseinā, kā ūdenstilpju daudzums, ezeru eitrofikācijas pakāpe, purvainums un veǵetācijas segums (Humborg et al. 2008).

Šì pētījuma mērḳis ir novērtēt silīcija koncentrācijas ilgtermiņa mainību Latvijas upēs.

\section{Materiāli un metodes}

Pētījumā iekḷauto upju (Daugava, Lielupe, Gauja, Venta, Salaca) sateces baseinu teritorijas pārklāj lielāko dalı Latvijas. Izmantotie dati ir iegūti Valsts Vides Monitoringa Programmas ietvaros un saṇemti no Latvijas Vides, Ģeologijas un 
Hidrometeorologijas centra, kā arī ievākti arhīva materiālos (Ūdens kvalitātes pārskati un gadagrāmatas). Izmantoti ikmēneša ūdens kvalitātes parametru ieraksti visam pētījuma periodam (1975-2014). Trendu analīzei izmantots Manna Kendala tests (Hirsch et al. 1982; Hirsch, Slack 1984; Libiseller, Grimvall 2002). Manna Kendalla tests lietots ar būtiskuma līmeni p<0,5, trends atzīts par statistiski būtisku, ja testa statistikas vērtība ir lielāka par 1,65 vai mazāka par -1,65.

\section{Rezultāti un diskusija}

Izšķk̄̄dušā silīcija koncentrācijas mainība Latvijas upēs ir raksturojama kā process, kam raksturīgas daudzgadīgas oscilācijas dabisku faktoru ietekmē. Tipiska silīcija koncentrācija Latvijas upju ūdeņos sastāda 1-3 mg/l. Kā redzam 1. attēlā, dažādās upēs koncentrācija ir atškirīga, tomēr atšḳirība nav l,oti liela. Statistiski visaugstākā koncentrācija ir novērojama Gaujā. Vidējā pētīto upju summārā silīcija plūsma sastāda ap 265 tonnām dienā ( $\approx 8000$ t mēnesī).

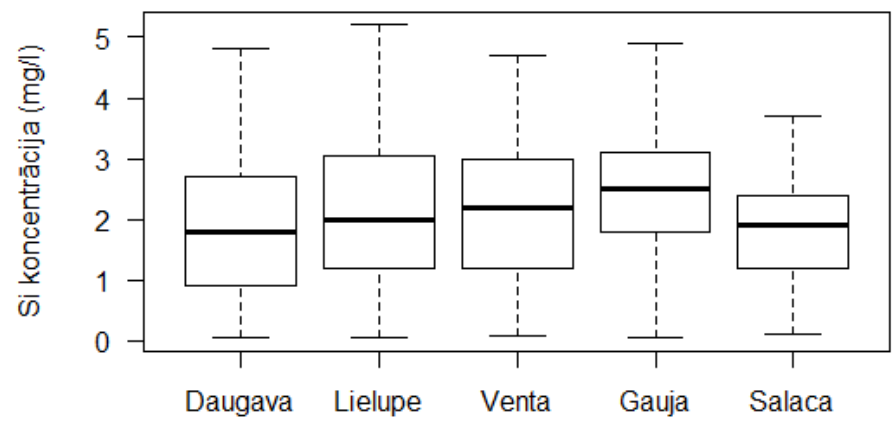

1. attēls. Izšḳīduša silīcija koncentrācijas Latvijas upju ūdeṇos (1980-2004)

Korelāciju analīze (1. tabula) rāda būtiskas kopsakarības starp silīcija koncentrāciju un noteci tikai Salacas gadījumā. Visās upēs redzama cieša sakarība starp ūdens reakciju $(\mathrm{pH})$ un izšķ̄īdušā silīcija koncentrāciju. Tāpat ir novērojama silīcija plūsmas saistība ar atsevišķiem citiem ķīmiskiem ūdens kvalitātes parametriem: nitrātu slāpekli, fosforu, dzelzi, organisko vielu, š̄i sakarība ir skaidrojama ar bioğeoḳīmiskajiem faktoriem.

1. tabula. Korelācijas koeficientu vērtības starp silīcija koncentrācijām un citiem hidroloğiskajiem un hidroḳīmiskajiem parametriem Latvijas upēs. Būtiskas vērtības izdalītas

\begin{tabular}{|c|c|c|c|c|c|c|c|}
\hline Silïcijs & $Q$ & $p H$ & Krāsainība & $N-N H^{4+}$ & $N-N O_{3}^{-}$ & $P-P O_{4}{ }^{--}$ & Fe kop \\
\hline Daugava & 0.003 & $\mathbf{- 0 . 1 9 3}$ & $\mathbf{0 . 1 9 5}$ & 0.155 & $\mathbf{0 . 2 1 8}$ & $\mathbf{0 . 3 0 1}$ & $\mathbf{0 . 3 6 0}$ \\
\hline Lielupe & 0.041 & $\mathbf{- 0 . 3 5 4}$ & 0.072 & 0.087 & $\mathbf{0 . 2 5 5}$ & -0.063 & $\mathbf{0 . 2 9 8}$ \\
\hline Gauja & 0.026 & $\mathbf{- 0 . 4 0 8}$ & 0.137 & 0.004 & $\mathbf{0 . 1 9 3}$ & $\mathbf{0 . 2 4 3}$ & $\mathbf{0 . 2 1 1}$ \\
\hline Venta & 0.137 & $\mathbf{- 0 . 2 1 2}$ & $\mathbf{0 . 1 6 8}$ & 0.185 & $\mathbf{0 . 4 1 9}$ & $\mathbf{0 . 3 4 2}$ & $\mathbf{0 . 2 9 5}$ \\
\hline Salaca & $\mathbf{0 . 3 5 8}$ & $\mathbf{- 0 . 3 7 7}$ & $\mathbf{0 . 3 4 7}$ & -0.012 & $\mathbf{0 . 3 6 2}$ & $\mathbf{0 . 1 6 7}$ & $\mathbf{0 . 1 6 4}$ \\
\hline
\end{tabular}


Kā redzam 2. attēlā, statistiski būtiski trendi ir novērojami visās upēs. Daugavas gadījumā trends ir dilstošs, savukārt pārējos gadījumos augošs. Visnozīmīgākais silīcija koncentrācijas palielinājums pētāmajā periodā ir novērojams Salacas upē. Visticamāk, ka apskatāmie trendi ir vērtējami kā dabisko hidroloǵisko un hidroǵeoloǵisko ciklu izpausmes.

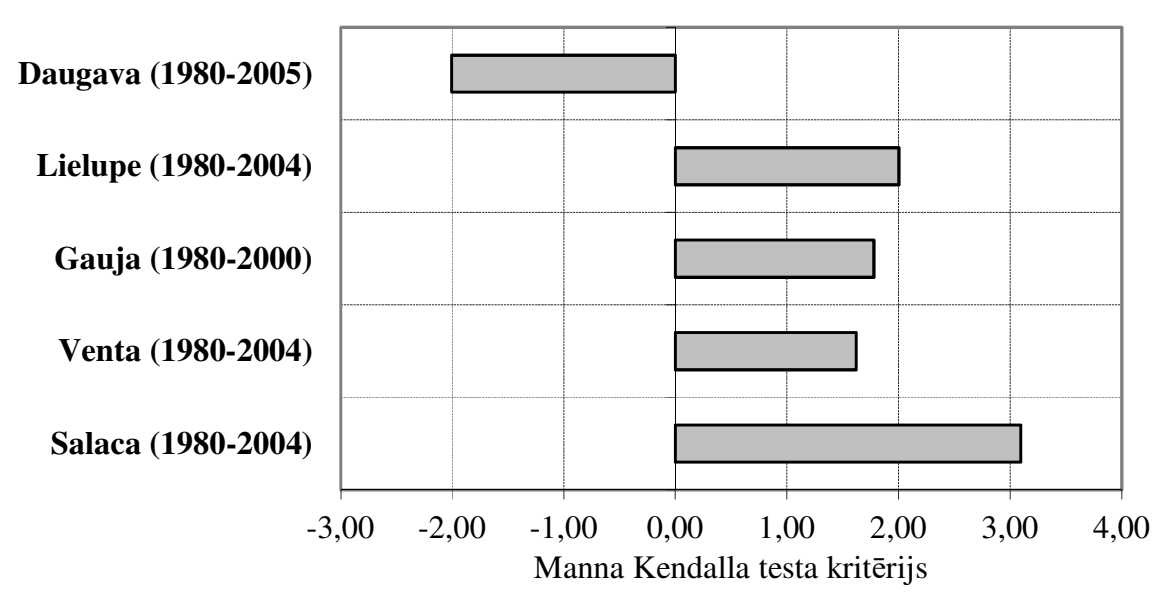

2. attēls. Izšķīdušā silīcija koncentrāciju ilgtermiṇa trendi Latvijas upēs (Manna Kendala testa kritērijs)

\section{Pateicība}

Pētījums veikts ar LZP granta Klimata sistēmas stabilitātes izmainas un to ietekme uz ūdens kvalitāti limitējošo bioǵeoḳīmisko vielu plūsmām Latvijā” atbalstu.

\section{Atsauces}

Brakke, D.F., Landers, D.H., Eilers, J.M.. (1988). Chemical and physical characteristics of lakes in the Northeastern United States. Environ. Sci. Technol., 22(2), 155-163.

Brunet, R.C., Astin, K.B. (1999). Spatio-temporal variation in some physical and chemical parameters over a 25-year period in the catchment of the river Adour. J. Hydrol., 220, 209-221.

Conley, D.J. (2002). Terrestrial ecosystems and global biogeochemical silica cycle. Global Biogeochemical Cycles 1694, 1121-1134

Donohue, R., Davidson, A.W., Peters, N.E., Nelson, S., Jakowyna B. (2001). Trends in total phosphorus and total nitrogen concentrations of tributaries to the Swan-Canning Estuary, 1987 to 1998. Hydrol. Proc., 15, 2411-2434.

Ferrier, R.C., Edwards, A.C., Hirst, D., Littlewood, I.G., Watts, C.D., Morris, R. (2001). Water quality of Scottish rivers: spatial and temporal trends. Sci. Total Environ. ,265, 327-342.

Godwin, K.S., Hafner, S.D., Buff, M.F. (2003). Long-term trends in sodium and chloride in the Mohawk River, New York: the effect of fifty years of road-salt application., Environ. Pollut., 124, 273-281.

Hirsch, R.M., Slack, J.R. (1984). A nonparametric trend test for seasonal data with serial dependence. Water Resour. Res., 20(6), 727-732.

Hirsch R.M., Slack J.R. \& Smith R.A. (1982). Techniques of trend analysis for monthly water quality data. Water Resour. Res., 18(1), 107-121. 
Humborg, C., Smedberg, E., Medina, M.R., Morth, C.M. (2008). Changes in dissolved silica loads to the Baltic Sea- The effects of lakes and reservoirs. Journal of Marine Systems, $73,223-235$.

Interlandi, S.J., Crockett, C.S., (2003). Recent water quality trends in the Schuylkill River, Pennsylvania, USA: a preliminary assessment of the relative influences of climate, river discharge and suburban development. Wat. Res., 37, 1737-1748.

Klavins, M., Briede, A., Rodinov, V., Kokorite, I., Parele, E., Klavina, I. (1999). Heavy metals in rivers of Latvia. Proc. Latv. Acad. Sci, ser. B, 53(1), 41-48.

Löfgren, S., Gustafson, A., Steineck, S., Stålnacke, P. (1999). Agricultural development and nutrient flows in the Baltic States and Sweden after 1988. Ambio, 28(4), 320-327.

Libiseller, C. \& Grimvall, A. (2002). Performance of partial Mann-Kendall tests for trend detection in the presence of covariates. Environmetrics, 13, 71-84.

Poršņovs, D., Kḷaviņš, M. (2016), Saules starojuma mainības ietekme uz dzelzs un silīcija plūsmām Latvijas upēs. LU Zinātniskā konference.

Raguneau, O., Conley, D.J., DeMaste,r D.J., Durr, H.H., Dittert, N. (2009). Si transformations along the land-ocean-continuum: Implications for the global carbon cycle. Liu K.K., Atkinson L., Quinones R., Talaue-McManus L. (Eds.), Carbon and nutrient fluxes in continental margins. Global Change - The IGBP Series. Berlin: Springer

Stålnacke, P., Grimvall, A., Libiseller, C., Laznik, M., Kokorite, I. (2003). Trends in nutrient concentrations in Latvian rivers and the response to the dramatic change in agriculture. J Hydrol, 283, 184-205.

Zhang, J., Yan, J. , Zhang, Z.F. (1995). Nationwide river chemistry trends in China: Huanghe and Changjiang. Ambio, 24(5), 275-279.

\section{Summary}

Studies of long term changes in aquatic chemistry composition are of importance to understanding the impacts of global climate change and human impacts. Dissolved silica is an important nutrient (primarily for siliceous phytoplankton, the diatoms, but also for macrophytes) in freshwater and marine ecosystems. The objective of the present study is to examine long-term changes in dissolved silica concentrations in surface waters of Latvia. Significant changes in silica concentrations in inland waters of Latvia were found. Results indicate possible impacts of weathering processes in combination with changes of human loading. 